\title{
ENKELE GRONDLEGGENDE GEDAGTES OOR DIE SOSIALE STUDIE-LEERGANG VIR DIE TRANSVAALSE LAERSKOLE.
}

In 'n vorige artikel is op grond van 'n samevattende prinsipieel-kritiese beskouing 'n antitese van die gangbare opvatting en toepassing van die Sosiale Studies van Amerika en Engeland gegee.

Op hierdie negatiewe beskouing volg die tetiese, die positiewe opvatting en die toepassing van die Sosiale Studies

KOERS deur die Christengelowige en by name die CALVINIS in die onderwys en opvoeding van die laerskooljeug oor die hele wêreld.

Hiermee konstateer die skrywer met nadruk soos blyk uit sy navorsing dat ook die CALVINIS die Sosiale Studies kan en mag doseer. Die afwysing van 
die Sosiale Studies as die vrug van die Opvoedkundige Sosiologie van Amerika en Engeland beteken nog geensins dat die doserinng van die Sosiale Studies alleenlik die voorreg van die genoemde twee lande en hulle navolgers is nie. Inderdaad is daar gewis ook plek vir die onderwys en opvoeding van die Sosiale Studies in die opvoedingsbeskouing wat gefundeer is in die Calvinistiese lewensen wêreldbeskouing.

Die Calvinis wil allermins in isolasie leef en nog minder wil en mag hy toesien dat sy kinders of jeug mag voortleef in afsondering van die komplekse dinamiese aard van die menslike samelewing, waarby elkeen gesonde aansluiting deur onderwys en opvoeding moet vind.

Op grond van die Calvinistiese lewens- en wêreldbeskouing as die slagaar van sy opvoedinngsbeskouing kan hierdie rigting inderdaad tot openbaring kom in die onderwysstelsel van die Sosiale Studies t.o.v.: die uitgangspunt, die mensbeskouing, die doelstelling, die inhoud van die leerstof, die metode en tug, en administrasie en organisasie.

In plaas van die oorbeklemtoning van die sosiologiese aspek in die Teoretiese Opvoedkunde, wat by die Humanisme en by name die Sosialisme met sy pragmatistiese en eksperimentalistiese uitingsvorme sterk na vore tree en oorbeklemtoon word, word die genetiese opvatting gehandhaaf.

Die aard van die onderwys met die Sosiale Studies word gekenmerk deur die analitiese en die estetiese interpretasie van die struktuur van die skoonheid in die skepping. Dit wil sê die feitlike gegewens wat die Opvoedkundige Sosiologie vir die Teoretiese Opvoedkunde lewer word gebuig onder die norme en prinsipia van die Teoretiese Opvoedkunde of is tewens nie daarmee in stryd nie.

Met hierdie beskouing oor die Sosiale Studies as die vrug van die Opvoedkundige Sosiologie, is laasgenoemde struktuurwetenskap van die menslike samelewing in wisselwerking met die opvoedkundige lewensterrein waarin die skool in die middelpunt en tog gekoördineerd en neweskikkend met die ander samelewingsvorme staan. Maar dan ook so dat hierdie Opvoedkundige Sosiologie as selfstandige tak van wetenskap in die raam van die Teoretiese Opvoedkunde pas.

Op hierdie wyse alleen is dit moontlik om die kosmiese samehang en verband tussen al die aspekte in hulle onderskeie toegeskape plekke in die geheel te handhaaf.

Meer nog, met hierdie beskouing bied ook die Sosiale Studies hulp en steun aan en kulmineer uiteindelik in die geloofsinterpretasie van die kerk. Op hierdie wyse gesien is alle onderwys en dus ook die van die Sosiale Studies deel van die opvoeding om die kind as mens volwaardig toe te rus vir 'n eie plek in die geskiedenis: vir die lewe duskant maar ook vir die lewe in die hiernamaalse. Dus alle onderwys as deel van die opvoeding is in sy wese ' $n$ heenlei en heenwys na BO.

Hierdie kort uiteensetting is die positiewe beskouing oor die Sosiale Studies in die kader van die Calvinistiese lewens- en opvoedingsbeskouing. 
Die voorgestelde Sosiale Studiesleergang vir die Transvaalse laerskole behoort te voorsien in, of altans ' $n$ bydrae te lewer tot ons Suid-Afrikaanse histories-geworde Christelike en nasionale lewens- en wêreldbeskouing. Hieraan is egter sekere voorwaardes verbonde, wat ons kortlike noem:-

1. Die navorser van hierdie vraag. stuk of probleem voel hom geroepe om 'n ernstige aanklag aan die adres van die onderwysowerhede te rig nl.: Is dit moontlik dat ' $n$ verantwoordelike onderwysowerheid 'n skoolvak soos Sosiale Studies kan invoer by die laerskole van 'n Provinsie sonder dat die onderwysers in hulle opleiding naas die andere ook behoorlik onderlê is in die selfstandige tak van wetenskap nl. Opvoedkundige Sosiologie? Ja, Opvoedkundige Sosiologie in die raam van die Teoretiese Opvoedkunde? DIE SOSIALE STUDIES IS DIE VRUG VAN DIE OPVOED-
KUNDIGE SOSIOLOGIE IN DIE KADER VAN DIE TEORETIESE OPVOEDKUNDE. Sonder die insluiting van o.a. die Opvoedkundige Sosiologie by die opleiding van onderwysers kan die dosering van die Sosiale Studies nie vrugte dra nie, wat wil nog sê gesonde vrugte! Die praktyk wys op die resultaat van die uitknip- en plakpraktyk en niks verder nie!

2. Mag in hierdie leemte by die opleiding van onderwysers spoedig voorsien word in die ernstige lig van die komplekse aard van die prosesse van sosiale verandering vir die gesonde aansluiting van en onderwyser en kind by 'n steeds veranderende menslike samelewing en kultuur wat 'n onverbreeklike drie-eenheid vorm. Dit is die weloorwoë mening en begeerte van die skrywer.

J. P. VAN DER WALT.

P.U. vir C.H.O. 